\title{
Forty years of change in forage fish and jellyfish abundance across greater Puget Sound, Washington (USA): anthropogenic and climate associations
}

\author{
Correigh Greene $^{1, *}$, Lauren Kuehne ${ }^{2}$, Casimir Rice ${ }^{3}$, Kurt Fresh ${ }^{1}$, Daniel Penttila ${ }^{4}$ \\ ${ }^{1}$ NOAA Fisheries, Northwest Fisheries Science Center, Seattle, WA 98112, USA \\ ${ }^{2}$ University of Washington, School of Aquatic and Fishery Sciences, Seattle, WA 98105, USA \\ ${ }^{3}$ NOAA Fisheries, Mukilteo Research Station, Mukilteo, WA 98275, USA \\ ${ }^{4}$ Salish Sea Biological, Anacortes, WA 98221, USA
}

\begin{abstract}
Coastal ecosystems face a variety of natural and anthropogenic influences, raising questions about mechanisms by which species abundance and composition change over time. We examined these questions by synthesizing 6 surface-trawling efforts in greater Puget Sound, Washington (USA), spanning $40 \mathrm{yr}$, and then determining changes in forage fish abundance and composition and jellyfish prevalence. We also assessed whether patterns were associated with potential anthropogenic pressures (human population density and commercial harvest) as well as large-scale climate signals. We found evidence for trends in abundance of all forage species in 4 sub-basins of Puget Sound. Cumulative distribution functions of catch per unit effort indicate that the historically dominant forage fishes (Pacific herring and surf smelt) have declined in surface waters in 2 sub-basins (Central and South Puget Sound) by up to 2 orders of magnitude. However, 2 other species (Pacific sand lance and three-spine stickleback) increased in all 4 sub-basins. Consequently, species composition diverged among sub-basins over the last $40 \mathrm{yr}$. In addition, jellyfish-dominated catches increased 3- to 9-fold in Central and South Puget Sound, and abundance positively tracked human population density across all basins. The strongest predictors of forage fish declines were human population density and commercial harvest. Climate signals offered additional explanatory power for forage fish but not jellyfish catch. These patterns suggest possible linkages between coastal anthropogenic activities (e.g. development, pollution) and the abundance of forage fish and jellyfish in pelagic waters. Our findings also provide a basis for improving indicators for assessment, monitoring, and spatial planning to rehabilitate pelagic ecosystems.
\end{abstract}

KEY WORDS: Pacific herring - Surf smelt - Pacific sand lance - Three-spine stickleback · Gelatinous zooplankton $\cdot$ Human population density $\cdot$ Climate $\cdot$ Commercial harvest

\section{INTRODUCTION}

Coastal pelagic environments are important in marine and lacustrine systems because of their productivity and role as nursery habitats (Beck et al. 2003, Dahlgren et al. 2006). Within marine waters, numerous fish and wildlife species occupy pelagic habitats for portions of their life cycle. Anadromous fish such as salmon use pelagic habitats during both juvenile and adult phases, and demersal fish often make forays into pelagic waters to feed and to move.

*Corresponding author: correigh.greene@noaa.gov
However, the dominant members of fish assemblages in these areas are generally forage fish: highly productive, short-lived planktivores that mature at a relatively small body size (Pikitch et al. 2012). Due to their low diversity but high potential productivity and numerical abundance, forage fish have the capacity to regulate patterns of energy flow in pelagic ecosystems, and therefore play critical roles in pelagic ecosystems as both predators of zooplankton and prey for piscivorous fish, birds, and marine mammals (Cury et al. 2000, Bakun 2006). Both theoretical

(C) Kuehne, Penttila 2015. Open Access under Creative Commons by Attribution Licence. Use, distribution and reproduction are unrestricted. Authors and original publication must be credited. 
and statistical modeling studies have confirmed that the abundance of forage fish can influence the dynamics of both their predators and prey (Cury et al. 2000, Griffiths et al. 2010). For example, a robust threshold between productivity of seabird populations and forage fish biomass led Cury et al. (2011) to recommend that managers allocate one-third of forage fish biomass to seabirds and other piscivores to avoid drastic population declines of these predators.

Because of their trophic importance, concern has grown about declines in forage fish stocks in many regions, and the potential shifts in species composition that may result from their decline. Historically, forage fish have often been heavily harvested, and in some areas, species composition has subsequently become dominated by gelatinous zooplankton ('jellyfish') (Lynam et al. 2011, Flynn et al. 2012, Purcell 2012). In addition to commercial harvesting, anthropogenic pressures such as climate change, hypoxia, and coastal development may positively benefit jellyfish (Parsons \& Lalli 2002, Purcell et al. 2007, Richardson et al. 2009, Purcell 2012) at the expense of forage fish. Jellyfish are often considered trophic 'dead ends' (Purcell et al. 2007, Richardson et al. 2009) because very few predators are specialized to obtain nutritional benefits by preying on them, yet they may compete with adult forage fish or consume larval stages of fish (Pauly et al. 2009). Hence, declines in forage fish and increases in jellyfish are considered possible ecological warning signs of reduced trophic capacity (Purcell et al. 2007, Richardson et al. 2009, Pauly et al. 2009, Rice et al. 2012). Unfortunately, long-term datasets on coastal forage fish species and jellyfish are rare. Most long-term status monitoring has focused on larger-bodied, commercially important species, and regular assessments of smaller or unfished pelagic organisms are not routinely done (Lauria et al. 2012).

Here, we synthesize historical data from neritic surface trawling efforts in an urbanizing fjord estuary complex and compare these with more recent surveys using the same sampling gear. In Puget Sound, Washington (USA), long-term monitoring for forage fish has largely focused on surveys for spawning adult herring (Penttila 2007), and has not examined the full suite of pelagic species at varying life stages. In the absence of long-term data, we took advantage of short-term monitoring efforts targeting juvenile herring and other forage fish which were conducted in the 1970s and 1980s across Puget Sound (e.g. Stober \& Salo 1973, Fresh 1979) and have been repeated in more recent years as part of juvenile salmon and pelagic food web studies (Reum et al. 2011, Rice et al.
2012). This comparison is by nature a data-limited time series (see Araujo et al. 2013), yet it nevertheless provides an opportunity to examine (1) whether pelagic forage fish and jellyfish have exhibited changes in abundance and taxonomic composition over the last $40 \mathrm{yr}$, and (2) whether such changes correspond with regional climate patterns and anthropogenic drivers.

\section{MATERIALS AND METHODS}

\section{Study system}

Puget Sound is a large fjord estuary complex connected to the northeast Pacific Ocean via the Salish Sea (Fig. 1), and has numerous rivers flowing into 6 sub-basins separated by sills, landforms, and hydrographic fronts (Burns 1985, Ebbesmeyer et al. 1988). This geomorphology results in extended water residency, stratification, and strong primary production (hence, 'the fertile fjord', Strickland 1983) across Puget Sound as a whole. The oceanographic properties of individual sub-basins vary with differing freshwater inputs and circulation patterns (Moore et al. 2008). Historically, extensive estuarine and nearshore habitats such as beaches, seagrass, and kelp existed for spawning and rearing by forage fish and other species in all sub-basins. These systems have been lost or degraded over time (Simenstad et al. 2011), but evidence suggesting that loss of these habitat features has directly impacted forage fish populations is limited (Rice 2006). Broad-scale spatiotemporal trends in abundance and the direct effect of habitat loss on abundance have not been evaluated to date.

We focused on 4 sub-basins with surface trawl data spanning the last 40 yr (Fig. 1): South Puget Sound, the Central Basin, Whidbey Basin, and 'Rosario Basin' (areas north of Puget Sound proper). Subbasins are delineated based on physical and hydrologic features as described by Burns (1985) (South, Central, and Whidbey Basins) and Rice et al. (2012) (Rosario Basin). Fish sampling via Kodiak surface trawling has been conducted in these sub-basins both historically (1971-1985) and more recently (2002-2003, 2011; Table 1).

\section{Pelagic fish and jellyfish}

Our definition or 'forage fish' generally follows Pikitch et al. (2012): highly productive pelagic planktivores that maintain small $(<300 \mathrm{~mm})$ body size 

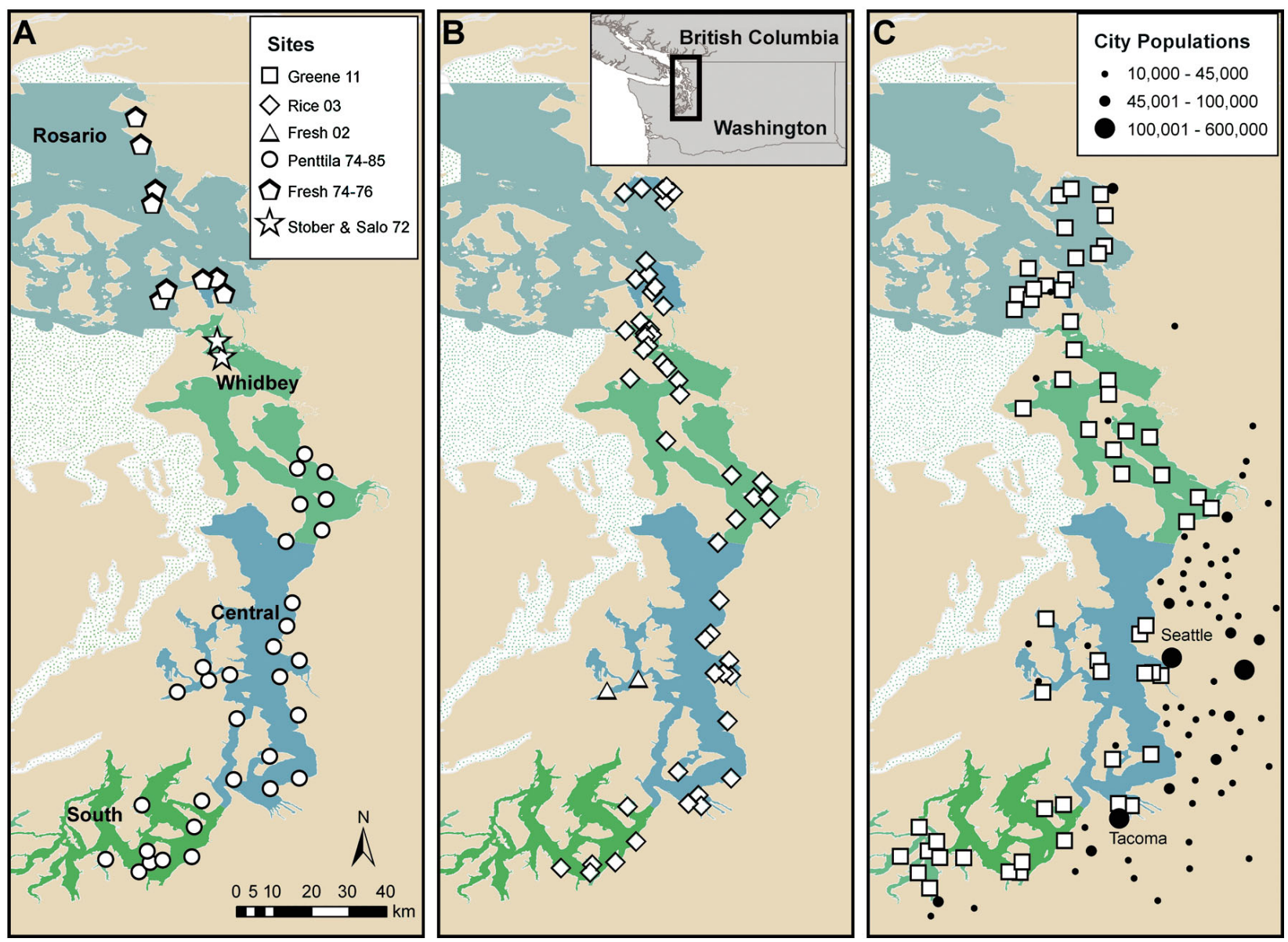

Fig. 1. Kodiak surface trawl sampling sites in greater Puget Sound, Washington (USA), over 3 time periods: (A) 1971-1985 (historical), (B) 2002-2003, and (C) 2011. Blue and green shades describe the extent of 4 sub-basins examined in this study (labeled in A), and stippled white areas are sub-basins not examined. Inset map in (B) shows greater Puget Sound in the context of its location in northwest North America and its larger Salish Sea bioregion. Sites included for analysis from the various sampling efforts (see Table 1) are noted as different open shapes. In Panel C, black circles refer to major cities of different population size based on data compiled in 2007

throughout their life cycle. Puget Sound's pelagic waters are home to at least 7 native species that we categorized as forage fish: Pacific herring Clupea pallasii, surf smelt Hypomesus pretiosus, sand lance Ammodytes hexapterus, three-spine stickleback
Gasterosteus aculeatus, longfin smelt Spirinchus thaleichthys, eulachon Thaleichthys pacificus, and northern anchovy Engraulis mordax. The latter 3 are much rarer in occurrence than the first 4 (Penttila 2007, Rice et al. 2012), and eulachon is currently

Table 1. Summary of Kodiak trawl datasets in Puget Sound, Washington (USA), examined in this study. Basin abbreviations are S: South Sound, C: Central Basin, W: Whidbey Basin, and R: Rosario Basin. The number of tows reflects the subset of records used in data analysis, which included sampling done in the months of June to September only

\begin{tabular}{|lccccccc|}
\hline Time period & $\begin{array}{c}\text { Principal } \\
\text { investigator(s) }\end{array}$ & Basins & $\begin{array}{c}\text { Number } \\
\text { of tows }\end{array}$ & $\begin{array}{c}\text { Site } \\
\text { selection }\end{array}$ & $\begin{array}{c}\text { Tow duration } \\
\text { (min) }\end{array}$ & $\begin{array}{c}\text { Time of } \\
\text { day (\% of tows) }\end{array}$ & $\begin{array}{c}\text { Reference } \\
\text { (if available) }\end{array}$ \\
\hline $1971-1972$ & Stober \& Salo & W & 131 & Continuous tows & $3-5$ & Day (89) & Stober \& Salo (1973) \\
$1974-1976$ & Fresh & R & 86 & Index sites & 10 & Night (98) & Fresh (1979) \\
$1974-1985$ & Penttila & S, C, W & 494 & Index sites & $5-15$ & Night (94) & \\
2002 & Fresh & C & 17 & Index sites & 10 & Night (53) & Rice et al. (2012) \\
2003 & Rice & S, C, W, R & 392 & Index sites & 10 & Day (99) & Day (100) \\
2011 & Greene & S, C, W, R & 257 & Index sites & $5-10$ & Day & \\
\hline
\end{tabular}


listed as 'threatened' under the US Endangered Species Act.

A broad diversity of other species share pelagic habitats with forage fish in Puget Sound, although these species differ in their life history and management, and their variation in abundance or distribution is likely to be distinct from changes in forage fish populations. Benthic fish species that occasionally occur in the upper water column and are caught in surface trawls include flatfish such as starry flounder Platichthys stellatus, perches (Embiotocidae), rockfishes (Sebastes spp.), bay pipefish Syngnathus leptorhynchus, and sculpin (Cottidae) (see Table S1 in the Supplement at www.int-res.com/articles/suppl/ m525p153_supp.pdf). As these fish prefer bottom habitats, surface trawl sampling is not expected to accurately assess their presence, abundance, or distribution throughout Puget Sound. Nevertheless, many trawl samples included members of these groups, and some of these species share similar trophic roles as forage fish at particular life stages (e.g. post-larval stages of sculpin). We grouped these benthically-oriented species into a 'demersal' group for the purposes of coarse comparison to overall forage fish catch per unit effort (CPUE, $\mathrm{n} \mathrm{min}{ }^{-1}$ ).

In addition to various demersal species, 7 species of salmon and trout (Oncorhynchus spp.) have juvenile life stages in Puget Sound that overlap in space and time with forage fish. These salmon populations prized as adults in commercial and recreational fisheries - have been extensively supplemented by hatcheries, with large variation in production practices over the last 50 yr. Partly as a result of changes in hatchery practices, salmon captured in earlier historical surveys (pre-1990) were not well differentiated as hatchery or wild fish, nor were salmon consistently identified to species. As with demersal species, salmonids were therefore classified into a 'salmon' group for comparing abundance and distribution with forage fish CPUE.

In addition to fish, at least 6 species of gelatinous zooplankton or 'jellyfish' are common in Puget Sound and large enough to be sampled by Kodiak trawls: water or crystal (Aequorea spp.), moon Aurelia labiata, cross Mitrocoma cellularia, lion's mane Cyanea capillata, fried-egg Phacellophora camtschatica, and umbrella Clytia gregaria jellyfish. In addition to the cnidarian jellyfish, ctenophore comb jellyfish (Pleurobrachia spp.) are quite common. While these species vary in their diets and other habits, they were not well distinguished by fisheries researchers until recently and were lumped into a general category of 'jellyfish' when biomass was recorded (Rice et al.
2012). To assess changes in jellyfish biomass, we focused on large jellyfish catches (which were consistently recorded), and compared them with recent data meeting the same high-biomass criteria.

\section{Integrating trawl data}

Fish datasets

We obtained counts of forage fish, salmon, and benthic species from historical monitoring efforts that employed Kodiak trawls to sample fish and other organisms in surface nearshore pelagic waters (Table 1, Fig. 1). A Kodiak trawl net (cod-end mesh size of $6 \mathrm{~mm}$ ) is deployed at the surface by 2 boats via $50 \mathrm{~m}$ towlines connected to vertical metal posts, and sweeps a $3.1 \mathrm{~m}$ high $\times 6.1 \mathrm{~m}$ vertical plane in the water column when fully open (Rice et al. 2012). Trawling programs included an extensive multi-year survey primarily in South Sound and Central Basin, and targeted surveys of Skagit Bay in Whidbey Basin (Stober \& Salo 1973), and embayments of the Rosario Basin and the nearby San Juan Islands (Fresh 1979). We compared data from these historical surveys to extensive recent surveys in 2003 and 2011 (Reum et al. 2011, Rice et al. 2012) that sampled all 4 basins. Site selection depended upon each survey's purpose, but some historical sites were revisited in the recent surveys. Because historical surveys were usually conducted from June through September, we restricted data from both historical and recent surveys to those 4 months to reduce seasonal variation.

The primary differences across sampling efforts were in trawl duration and time of sampling. Trawl duration ranged from 3 to $15 \mathrm{~min}$ in the 1970s and from 5 to $10 \mathrm{~min}$ in recent surveys (Table 1). In earlier historical surveys, the majority of sampling occurred at night, but more recent surveys were largely conducted during the day. While trawl duration can be corrected readily by calculating CPUE (i.e. $\mathrm{n} \mathrm{min}{ }^{-1}$ ), correcting for differences in time of sampling is more complicated. Diel vertical movements are common for many pelagic species as a way to track food resources and avoid predation, and can result in statistically different catch rates between day and night (Krutzikowsky \& Emmett 2005). The difference in time of sampling between historical and recent surveys necessitated careful examination of day:night ratios and adjustment of daytime catch data.

Each dataset typically contained a number of day to night comparisons conducted at the same sites within $24 \mathrm{~h}$. Comparisons from these paired tows 
provided a means to test whether species-specific diel activity patterns influenced catch. Using Wilcoxon signed rank tests, we compared whether matched samples of organisms were similar in day and night at the same sites. Surprisingly, most species did not exhibit significant differences in day and night CPUE, except Pacific sand lance (nocturnal), salmon (diurnal), and benthic species (nocturnal; Table 2). Nevertheless, ratios of day:night CPUE averaged across sites could be substantial, and at least 1 species (longfin smelt) was completely absent in the entire dataset of day tows.

Hence, we used the day:night ratios to develop 3 representations of the data: raw CPUE, CPUE from night sampling converted to day values (Day CPUE), and CPUE from day sampling converted to night values (Night CPUE). Day CPUE provides the fullest complement of information because night sampling has higher species diversity, while Night CPUE retains much of the actual historical catch values. We tested for temporal and spatial contrasts in these 3 data representations, and found that species abundance and composition for all 3 representations were strongly correlated with each other in space and time. Hence, any conclusions about broad changes in forage fish or jellyfish abundance and distribution over time are not likely to have been affected by the time of day of sampling. For consistency, we report forage fish results in terms of Day CPUE to maximize inclusion of species.

Consistent biases could also potentially result from vagaries in deployment and towing protocols between historical and recent surveys. If such differences existed, we expected these to most directly affect the size distribution of fish captured (i.e. faster tow speeds or more efficient deployment and retrieval of the net should result in catches of larger fish). We examined differences between the size distribution of juvenile herring caught in the broadest historical survey (D. Penttila's cruises, see Table 1) and the most recent surveys (Greene et al.'s cruises, Table 1) in July, a month dominated by young-of-the year herring. We found that the minimum $(t=16.5, \mathrm{p}<0.01)$, average $(t=19.1, \mathrm{p}<0.01)$, and maximum $(t=9.2, \mathrm{p}<$ 0.01 ) lengths (summarized by tow) were greater in the 2011 surveys compared to 1976 to 1985 surveys. These differences persisted even when adjusted by average size measured a month earlier to correct for measurement biases and year-specific differences in juvenile growth (e.g. due to annual variation in temperature or food availability). Hence, catch efficiency appeared greater for recent survey protocols.

\section{Jellyfish}

Measurements of jellyfish catches in surveys have improved over time. During the 1970s and 1980s, jellyfish biomass was often not measured. The exception to this was in Central and South Sound surveys in cases where jellyfish dominated the catch. In 2003, Rice et al. (2012) measured total jellyfish biomass for each catch, and in 2011, biomass of each species was measured. Because of the historical measurement bias, analysis of temporal changes in jellyfish necessitated a different approach than we used for fish. We first examined the distribution of biomass for which jellyfish were measured in historical surveys, and found that jellyfish catches were consistently recorded only when their biomass was equal to or greater than $250 \mathrm{~g}$ during a $10 \mathrm{~min}$ tow. We therefore calculated the frequency of historical tows which surpassed this biomass criterion. Because the historical estimate was made solely on data collected at night, we applied the $\geq 250 \mathrm{~g}$ threshold rule to Night CPUE (based on biomass for jellyfish) for 2003 and 2011 catches to determine whether the frequency of large jellyfish catches changed over time. We used this threshold to filter the entire dataset, allowing us to 
examine above-threshold CPUE $\left(\mathrm{kg} \mathrm{min}^{-1}\right)$ at the resolution of individual tows.

\section{Anthropogenic and natural influences}

We tested the hypothesis that anthropogenic or climate drivers have impacted forage fish and jellyfish abundance over time. Given the variety of potential impact pathways through which humans might affect forage fish and jellyfish and the few degrees of freedom afforded by a discontinuous time series of forage fish and jellyfish in Puget Sound, we focused on 2 simple and direct metrics of anthropogenic influence: human population density and harvest of forage fish from commercial fisheries. Population density was derived from county estimates of the Washington State National Census surveys (http://wagda.lib. washington.edu/data/type/census/) measured each decade from 1900 through 2000 and yearly thereafter. We calculated annual human population density for years before 2000 by interpolating between decade values (see Fig. S1 in the Supplement). Human population density for each of the 4 sub-basins was obtained by averaging densities of their surrounding counties.

Herring and surf smelt have historically been commercially harvested, and relatively small operations continue. We summarized annual commercial landings data available from the Washington State Department of Fish and Wildlife (Stick \& Lindquist 2009; K. Stick pers. comm.) by sub-basin. Although recreational fisheries exist on herring, smelt, and anchovy, estimates of effort and harvest have been episodic and geographically focused; thus we could not consider this source of mortality.

In order to examine whether forage fish and jellyfish patterns of abundance could be ascribed to geographic or large-scale climate drivers, we summarized several metrics: the North Pacific Gyre Oscillation (NPGO), the Pacific Decadal Oscillation (PDO), the Southern Oscillation index (SOI), and the Upwelling Index (UWI) at Neah Bay off the outer entrance to the Strait of Juan de Fuca. The NPGO describes oscillations of sea level pressure and temperature across the North Pacific Ocean (Di Lorenzo et al. 2008; data available at www.o3d.org/npgo/). The SOI measures the atmospheric properties of El Niño based on sea level pressure changes in the south Pacific Ocean (Trenberth \& Caron 2000; data at www.pfel.noaa.gov/products/). The PDO summarizes long-term patterns in temperature and precipitation in the Pacific Northwest arising from a combi- nation of climate drivers in the Pacific Ocean, and has a periodicity of 20 to $30 \mathrm{yr}$ (Mantua et al. 1997). The UWI summarizes vectors of wind speed and direction, with positive values representing stronger north winds favorable for upwelling along the Pacific coast (Schwing \& Mendelssohn 1997; data available at www.pfel.noaa.gov/products/).

In addition, we used bathymetric datasets (Finlayson et al. 2000) in ArcGIS to estimate the average depth for each site, using a $1 \mathrm{~km}$ radius buffer around sampling locations with land screened out. Bathymetric data were not available for 5 sites; for these we used average depth measured during sampling. Datasets on local or basin-scale water quality characteristics (e.g. temperature, turbidity, dissolved oxygen) were lacking for early years, so they were not included as predictors.

We averaged values of climate indicators May through August to match the season of maximum growth for forage fishes, but also examined for potential time lags by comparing patterns with measurements averaged across January to April. Correlations of climate drivers with forage fish and jellyfish abundance metrics were uniformly stronger for the May through August time period, so we report these relationships only.

To reduce potential biases resulting from collinearity of predictors, we screened variables for strong correlations. Pearson correlations indicated significant covariation among climate indices (Table 3 ), and NPGO was the only variable strongly correlated $(\mathrm{p}<$ 0.05 ) with the other metrics (see also Fig. S1). In contrast, climate indicators were not strongly correlated with sub-basin anthropogenic stressors, with 1 subbasin exception (commercial landings in South Sound correlated with NPGO and PDO). Consequently, we used 3 variables for statistical analysis with forage fish CPUE: NPGO, human population density, and commercial landings.

We compared depth, climate, and anthropogenic predictors to metrics of forage fish and jellyfish status: total forage fish CPUE (combined count of all forage fish species caught per minute), and abovethreshold jellyfish CPUE (biomass per minute for tows with jellyfish $\geq 250 \mathrm{~g}$ ). Annual metrics of forage fish abundance were compared with annual metrics for climate, abiotic, and commercial landings data.

\section{Statistical analyses}

We used univariate and multivariate techniques to describe temporal and spatial differences in species 
Table 3. Pearson correlations of climate metrics and 2 anthropogenic stressors affecting Puget Sound, Washington (USA), across the time period of this study. Correlations among climate metrics (43 years) were computed independent of sub-basin, while correlations of climate metrics and anthropogenic stressors (42 years) were specific to subbasin. SOI: Southern Oscillation index, NPGO: North Pacific Gyre Oscillation, PDO: Pacific Decadal Oscillation, UWI: Upwelling Index. Asterisks indicate significant covariation of measures with climate indices $\left({ }^{*} \mathrm{p}<0.05\right)$

\begin{tabular}{|c|c|c|c|c|}
\hline & SOI & NPGO & $\mathrm{PDO}$ & UWI \\
\hline NPGO & $0.53^{*}$ & & & \\
\hline PDO & $-0.60^{*}$ & $-0.60^{*}$ & & \\
\hline UWI & -0.18 & $-0.49^{*}$ & 0.18 & \\
\hline \multicolumn{5}{|c|}{ Human population density } \\
\hline South & 0.00 & 0.22 & 0.08 & 0.00 \\
\hline Central & -0.01 & 0.21 & 0.08 & -0.01 \\
\hline Whidbey & -0.04 & 0.18 & 0.13 & 0.01 \\
\hline Rosario & -0.01 & 0.21 & 0.09 & 0.00 \\
\hline \multicolumn{5}{|c|}{ Commercial landings } \\
\hline South & -0.24 & $-0.47^{*}$ & $0.36^{*}$ & 0.11 \\
\hline Central & 0.06 & 0.12 & -0.04 & -0.10 \\
\hline Whidbey & 0.04 & 0.11 & -0.04 & 0.09 \\
\hline Rosario & 0.13 & -0.01 & -0.18 & 0.03 \\
\hline
\end{tabular}

composition and abundance. One of the challenges in comparing different datasets is accounting for inherent differences in the total number of samples (e.g. tows) and sampling locations. Therefore, to examine differences in CPUE for individual forage fish species between historical (1971-1985) and recent $(2002-2003,2011)$ datasets, we used Kolmogorov-Smirnov (KS) tests to compare cumulative distribution functions of herring, surf smelt, sand lance, and stickleback catch, the 4 species for which we had sufficient data in each basin. Significant test results indicated species and basin combinations exhibiting the largest differences in abundance between the 3 different time periods.

Next we conducted multivariate analysis using non-metric multidimensional scaling (NMDS) to visualize differences in overall species composition between historical and recent datasets. NMDS is an ordination technique that uses an iterative approach to converge on the best representation of relationships among samples and has outperformed many other ordination techniques in the analysis of community datasets (Clarke 1993, Clarke \& Warwick 2001, McCune et al. 2002). We conducted the ordination using Bray-Curtis similarity coefficients from log-transformed CPUE for all 6 forage fish species averaged at the level of Month $\times$ Basin $\times$ Time Period (Historical vs. Recent), and calculated the dissimilar- ities to indicate sub-basins with the largest shifts in species composition over time. Note that to examine and correct for potential biases due to differences between datasets in site selection, number of trawls, and seasonal timing of trawls, we averaged CPUE data in 3 combinations: (1) Month $\times$ Basin $\times$ Time Period, (2) Year $\times$ Basin $\times$ Time Period, and (3) Year $\times$ Site. All sets of aggregations produced similar patterns in basin level change over time periods, so for purposes of brevity we focused our analysis using the first combination. Analyses of similarity (ANOSIMs) were performed using PRIMER software (Clarke \& Gorley 2006) to detect changes in species composition within and among sub-basins. In addition, we tested for differences in multivariate dispersion (PERMDISP) between historical and recent conditions to determine whether compositional variation changed within sub-basins.

We used linear mixed effects models to test for effects of climate and anthropogenic pressures on total forage fish CPUE and above-threshold jellyfish CPUE. Mixed effects models are powerful statistical tools that are robust to missing data across time or sites (Zuur et al. 2009). Our analysis included site and month within site as random effects to account for variation across sampling efforts. We used 8 models to examine the relative influence of predictors modeled as fixed effects. The first model examined geographic predictors only (sub-basin and depth). The second model added NPGO as the best representative regional climate variable. Model 3 added the effect of commercial landings, Model 4 included human population density, and Model 5 included both human population density and commercial landings. Models 6 and 7 added interactions of subbasin with commercial landings and human population density, respectively. Model 8 included both interactions. We compared models using Akaike's information criterion (AIC), with the criterion of potential good models as those with $\triangle \mathrm{AIC}<7$ (Burnham \& Anderson 2002). For all analyses, total forage fish CPUE, above-threshold jellyfish CPUE, and commercial landings were $(\log +1)$-transformed, and human population density was log-transformed.

\section{RESULTS}

\section{How dominant are forage fish in the nearshore pelagic ecosystem?}

Forage fish CPUE exhibited strong spatial and temporal trends, and other species exhibited lower abun- 
dance and less variation (Fig. 2). Of the 3 main classes of fish captured in surface trawls (Fig. 2A-D), forage fish dominated catches and were historically at least an order of magnitude greater in abundance than salmon, the second-most common component of catch. In recent surveys, salmon catches have exceeded those of forage fish in South Sound and Central Basin (Fig. 2A,B), but forage fish still dominate in the northern basins (Fig. 2C,D). Within forage fish, Pacific herring, surf smelt, and Pacific sand lance dominated catch (Fig. 2E-H), but some of these species exhibited apparent declines even within the historical time period surveyed. Demersal fish represented the greatest diversity of catch (Table S1), but individual species were collected infrequently. Relative abundance of the 3 species groups appeared to shift over time within particular basins, and even when relative abundance of species groups stayed the same, contributions of particular species some- times changed. In particular, herring historically dominated Rosario Basin but have exchanged this position with three-spine stickleback in recent surveys (Fig. 2H).

\section{Has the distribution of species-specific catch changed over time in different basins?}

Examination of the pattern of species-specific CPUE across all tows revealed strong changes in the abundance of the more common species, and these temporal changes were basin-specific (Fig. 3). Cumulative distribution functions of CPUE for 4 forage fish species revealed over 5 orders of magnitude variation in abundance over space and time. Despite this variation, we observed strong $(p<0.05)$ speciesspecific differences in the distribution of CPUE across sampling time periods for each basin. South

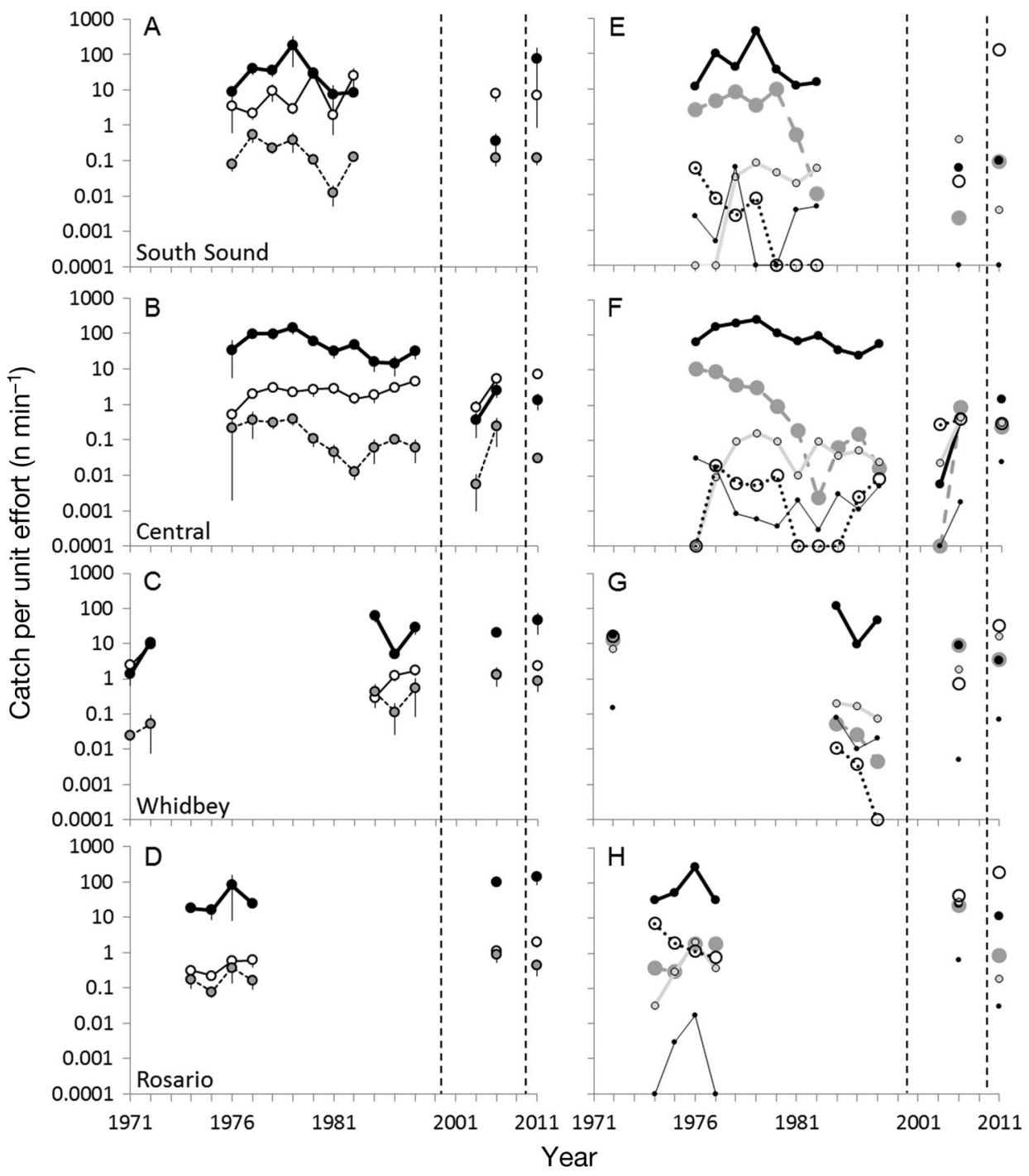

Fig. 2. Catch per unit effort $\left(\mathrm{n} \mathrm{min}^{-1}\right)$ of 3 species classes and forage fish species over time in Puget Sound, Washington (USA). (A,E) South Sound, (B,F) Central Basin, $(\mathrm{C}, \mathrm{G})$ Whidbey Basin, and $(\mathrm{D}, \mathrm{H})$ Rosario Basin. (A-D) Mean \pm SE annual catch per minute for forage fish (closed circles), salmon (open circles), and demersal fish (grey circles) in 4 basins of Puget Sound. (E-H) Mean catch per minute for herring (black circles and solid thick black line), surf smelt (large gray circles and dashed gray line), Pacific sand lance (small gray circles and solid gray line), three-spine stickleback (open circles with black dotted line), and northern anchovy (small black dots and solid black line). Vertical dashed lines denote large gaps in data collection. See Table S2 in the Supplement for data 

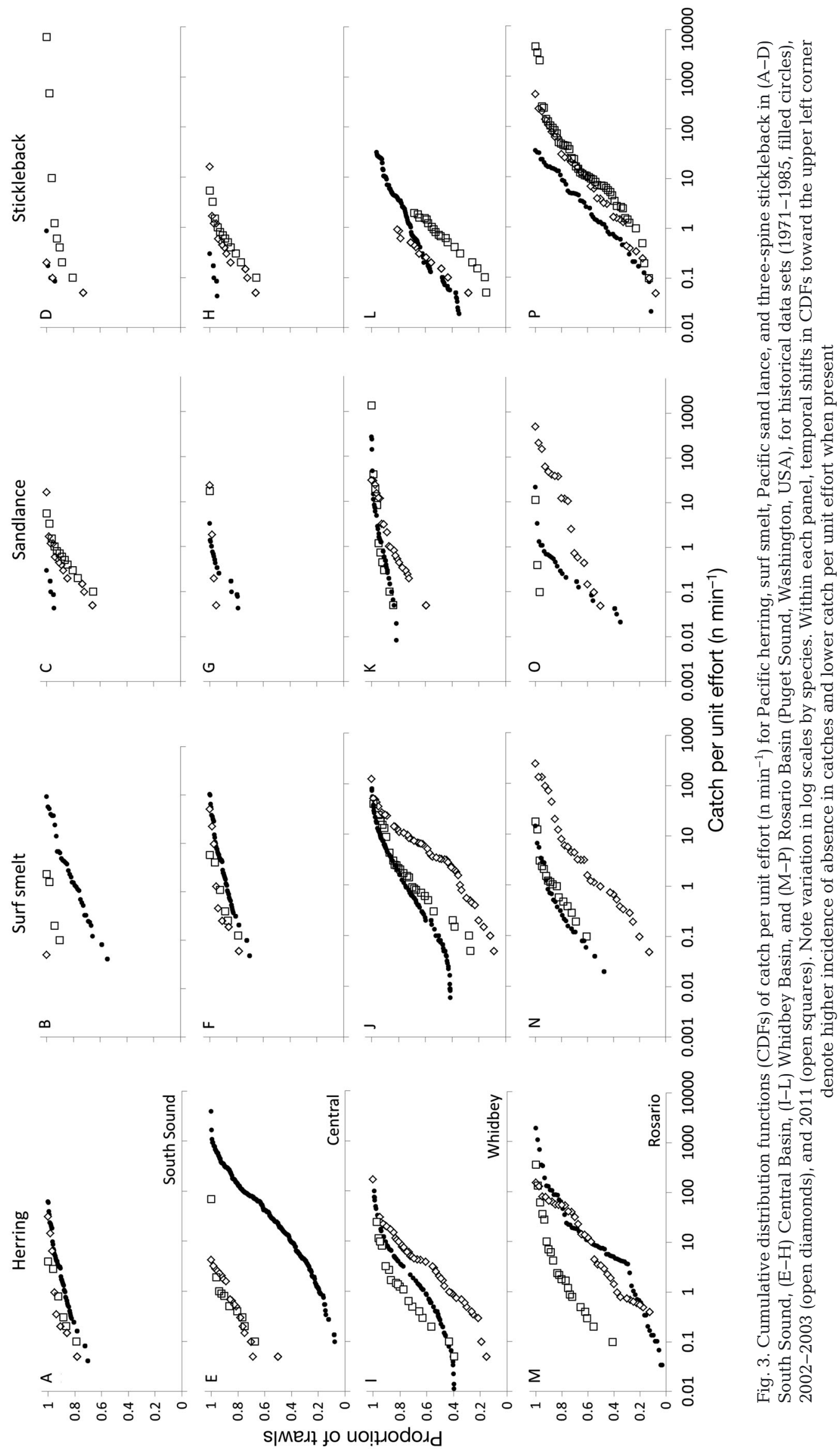
Table 4. Kolmogorov-Smirnov test results for differences in cumulative distributions across datasets, for 4 forage fish species in 4 basins in greater Puget Sound, Washington (USA). ${ }^{*} \mathrm{p}<0.05$

\begin{tabular}{|c|c|c|c|c|c|c|c|c|}
\hline & \multicolumn{2}{|c|}{ Herring } & \multicolumn{2}{|c|}{ Surf smelt } & \multicolumn{2}{|c|}{ Sand lance } & \multicolumn{2}{|c|}{ Stickleback } \\
\hline & 1971-1985 & $2002-2003$ & 1971-1985 & $2002-2003$ & 1971-1985 & $2002-2003$ & 1971-1985 & $2002-2003$ \\
\hline \multicolumn{9}{|l|}{ South } \\
\hline 2002-2003 & $0.73^{*}$ & & $0.42^{*}$ & & 0.09 & & 0.25 & \\
\hline 2011 & $0.69^{*}$ & 0.07 & $0.35^{*}$ & 0.12 & 0.07 & 0.12 & 0.17 & 0.12 \\
\hline \multicolumn{9}{|l|}{ Central } \\
\hline $2002-2003$ & $0.72^{*}$ & & 0.13 & & 0.17 & & $0.30^{*}$ & \\
\hline 2011 & $0.75^{*}$ & 0.17 & 0.08 & 0.07 & $0.20^{*}$ & 0.04 & $0.33^{*}$ & 0.08 \\
\hline \multicolumn{9}{|l|}{ Whidbey } \\
\hline $2002-2003$ & $0.31^{*}$ & & $0.44^{*}$ & & $0.25^{*}$ & & $0.16^{*}$ & \\
\hline 2011 & $0.19^{*}$ & $0.43^{*}$ & $0.24^{*}$ & $0.42^{*}$ & 0.04 & $0.25^{*}$ & $0.37^{*}$ & $0.34^{*}$ \\
\hline \multicolumn{9}{|l|}{ Rosario } \\
\hline $2002-2003$ & 0.25 & & $0.54^{*}$ & & $0.27^{*}$ & & 0.24 & \\
\hline 2011 & $0.59^{*}$ & $0.53^{*}$ & 0.13 & $0.49^{*}$ & $0.62^{*}$ & $0.48^{*}$ & $0.33^{*}$ & 0.14 \\
\hline
\end{tabular}

Sound (Fig. 3A-D) exhibited declines in both herring and surf smelt over time, as CPUE in both 2003 and 2011 sampling events differed from historical samples. For surf smelt, these differences amounted to over an order of magnitude change in median and maximum CPUE, and a similar loss in the probability of at least 1 individual captured. However, sand lance and stickleback did not exhibit major declines, and showed evidence of increases in CPUE in 3 of 4 sub-basins (Fig. 3, Table 4).

\section{Has community composition paralleled changes in species-specific catch?}

Following from the species-specific results, multivariate analysis of CPUE for all 6 species detected strong shifts in forage fish assemblage structure over time and space. When plotted in multi-dimensional space using NMDS (stress $=0.11)$, historical data $(1971-$ 1985) were tightly clustered, with recent data (2002-2011) exhibiting a 'fan' of divergence (Fig. 4). The primary drivers of variation (as shown by the species vectors) between historical and recent time periods were reductions in herring and surf smelt CPUE (Fig. 4). Multivariate centroids of historical and recent time periods were significantly different when tested using 2-way ANOSIM (global $\mathrm{R}=0.75$, $\mathrm{p}<0.01)$.
Changes in the multivariate centroids for each subbasin between recent and historical time periods were also significant (2-way ANOSIM, global $\mathrm{R}=$ $0.32, \mathrm{p}<0.01)$. This divergence over time was largely explained by the large and significant change in dispersion or variation around the centroid (PERMDISP $\mathrm{p}<0.05$ ) in South Sound and Central Basins, as well as directional change in the centroid of each subbasin (Fig. 4, Table 5). The ordination indicates that

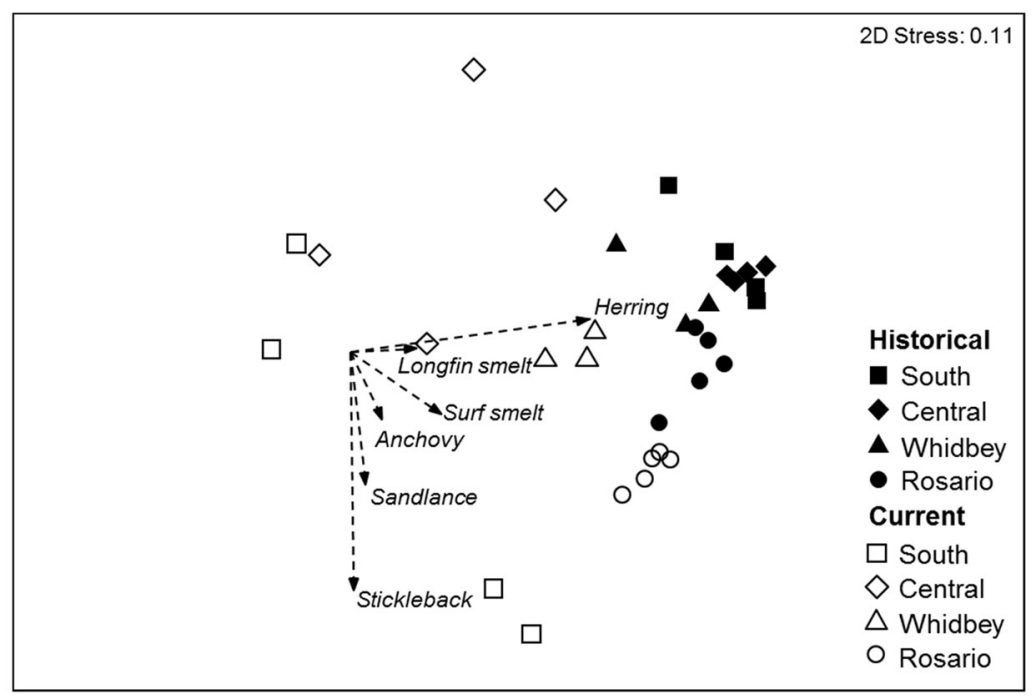

Fig. 4. Compositional change in Puget Sound (Washington, USA) forage fish based on 2-dimensional ordination of catch per unit effort (CPUE) for 6 species in historical (black symbols) and recent (white symbols) time periods. Species vectors are overlaid (dotted lines with arrows pointing in the direction of higher abundance) and describe the direction of change for that species and importance (vector length) of the species to the overall ordination. Each symbol represents the Bray-Curtis similarity scores aggregated by basin (see legend for symbols), month (June-September), and historical (1971-1985) vs. recent (2002-2011) time periods. Like a spatial map, larger distances among points indicate lower similarity 
Table 5. Bray-Curtis similarity scores averaged across basin, month, and historical (1971-1985) vs. recent (2002-2011) time periods. Dark gray cells compare historical data between basins, light gray cells compare historical with recent data within the same basin, and white cells compare recent data between basins. Parenthetical values indicate the ratio of dispersion (recent:historical) of the multidimensional centroids. Asterisks indicate significant differences $\left({ }^{*} \mathrm{p}<0.05\right.$, ANOSIM)

\begin{tabular}{|lccccc|}
\hline & South & Central & Whidbey & Rosario \\
\hline South & $13.3^{*}(2.3)$ & 78.6 & 63.0 & $63.3^{*}$ \\
Central & $27.0^{*}$ & $22.1^{*}(6.3)$ & $66.6^{*}$ & $72.0^{*}$ \\
Whidbey & $22.6^{*}$ & $34.3^{*}$ & $59.4^{*}(0.7)$ & 69.9 \\
Rosario & $27.4^{*}$ & $20.3^{*}$ & 65.4 & $52.6^{*}(0.9)$ \\
\hline
\end{tabular}

increasing cross-basin variation between time periods was related primarily to sand lance and stickleback abundance (Fig. 4).

While differences in the composition of forage fish species were significant $(p<0.05)$ in 3 of the 6 historical sub-basin comparisons, similarity scores were fairly high (Table 5). All sub-basins exhibited significant within-basin compositional change, but South
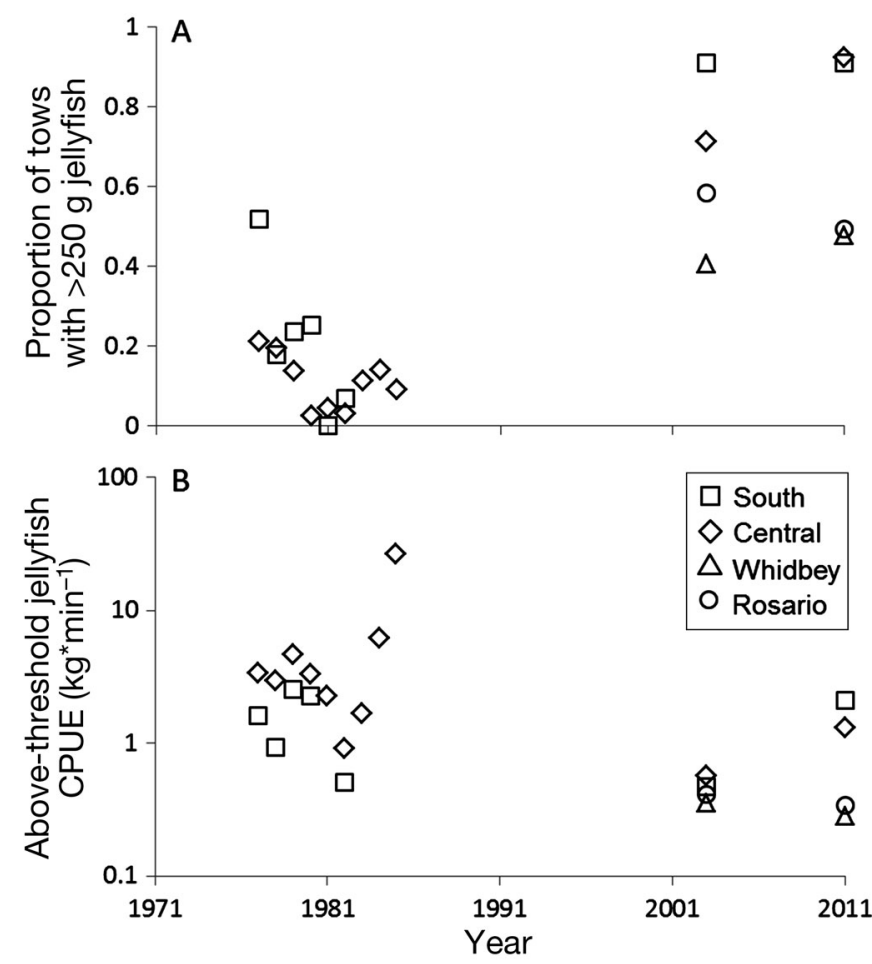

Fig. 5. (A) Proportion of tows with jellyfish biomass $>250 \mathrm{~g}$ for each sampled basin in Puget Sound, Washington (USA), by year. (B) Geometric mean of catch per unit effort (CPUE; $\mathrm{kg} \mathrm{min}^{-1}$ ) for tows surpassing the $250 \mathrm{~g}$ threshold. Note log-scale in (B)
Sound and Central Basin (the 2 more populous subbasins) exhibited much lower similarity between historical and recent time periods than Whidbey and Rosario Basins. Consequently, more recent sampling exhibited greater divergence across sub-basins, and the only comparison that did not exhibit significant divergence was that between Whidbey and Rosario Basin (Table 5).

\section{Have jellyfish catches changed over time?}

We detected evidence for large increases in the proportion of jellyfish-dominated catches in at least 2 sub-basins. Large catches of jellyfish increased from $27 \%$ to over $90 \%$ in South Sound, and from $10 \%$ to $61-92 \%$ in Central Basin (Fig. 5A), and these changes were highly unlikely to have occurred by chance (binomial tests, $\mathrm{p}<0.001$ ). However, abovethreshold CPUE did not exhibit strong annual trends over time (Fig. 5B).

\section{Do forage fish and jellyfish catches track changes in anthropogenic and natural pressures?}

Measures of forage fish and jellyfish status (total forage fish CPUE and above-threshold jellyfish CPUE) showed evidence of tracking natural and anthropogenic pressures, and anthropogenic pressures were the most informative predictors. In particular, the highly urbanized Central Basin exhibited a negative trend as a function of human population density (Fig. 6A), with the 3 other sub-basins showing a similar negative relationship but at lower population densities. In contrast, relationships between NPGO and total forage fish CPUE were quite variable across sub-basins, although a negative relationship was suggested across sub-basins (Fig. 6B). Comparisons of 8 models of total forage fish CPUE all revealed a strongly positive relationship with local depth and a negative relationship with regional NPGO (Table 6). However, geographic and climate signals were relatively poor predictors on their own, and the best models of total forage fish CPUE included strong negative relationships with both commercial landings and human population density. Based on changes in $\triangle \mathrm{AIC}$, human population density had much better explanatory power than commercial landings ( $\triangle$ AIC between Models 3 and $2=$ 8.15, $\triangle$ AIC between Models 4 and $2=105.86$ ), although both variables additively explained variation in total forage fish CPUE. We found particularly 

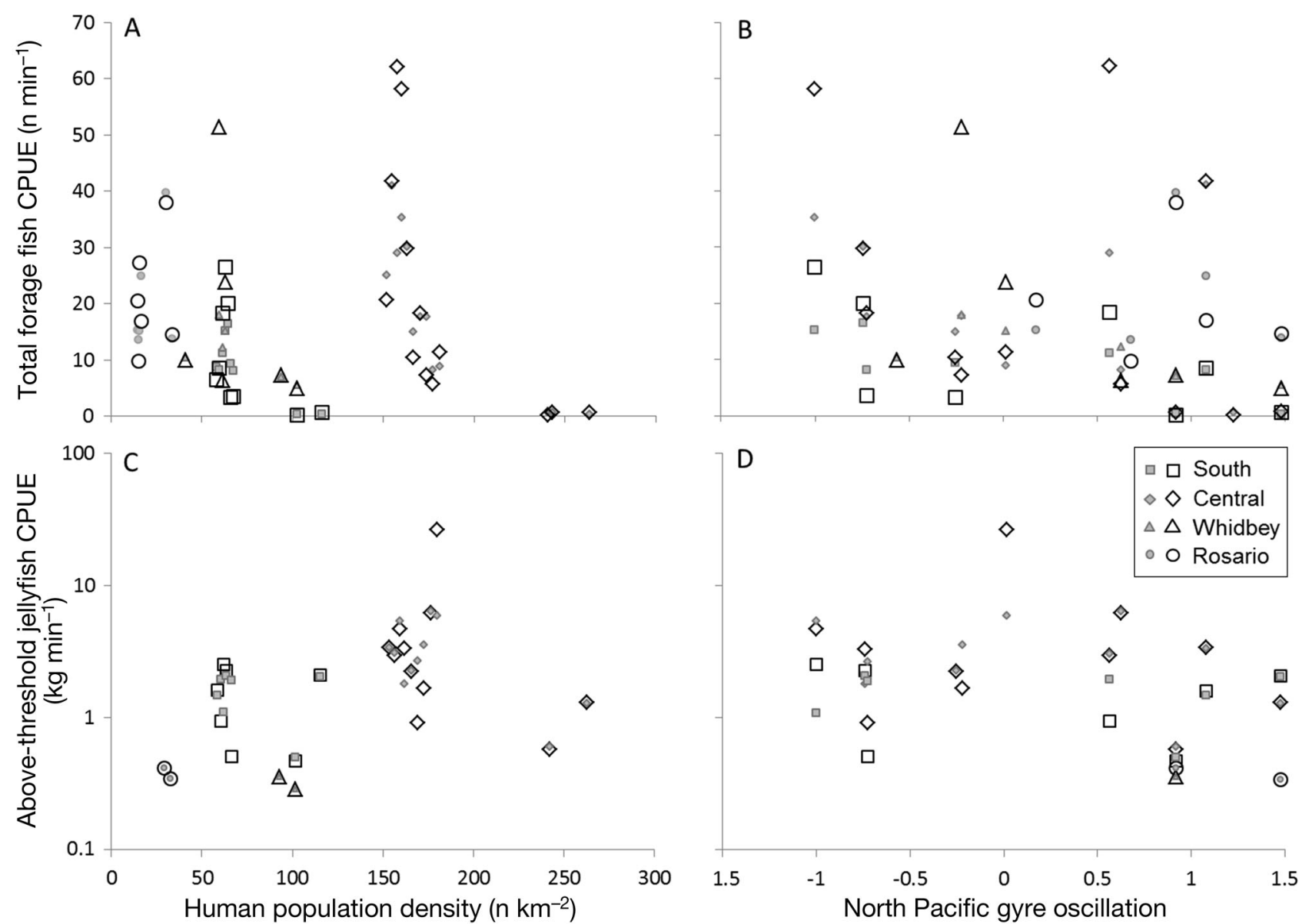

Fig. 6. (A,B) Total forage fish catch per unit effort (CPUE; $\left.\mathrm{n} \mathrm{min}{ }^{-1}\right)$ and $(\mathrm{C}, \mathrm{D})$ jellyfish geometric mean CPUE $\left(\mathrm{kg}\right.$ min $\left.{ }^{-1}\right)$ for tows surpassing $250 \mathrm{~g}$ in South Sound, Central Basin, Whidbey Basin, and Rosario Basin in Puget Sound, Washington (USA), as a function of human population density $(A, C)$ and NPGO $(B, D)$. Open symbols are actual observations, and small gray symbols are predicted values based on the best mixed effects model

strong support (model probability $>0.99$ ) for a model that included geographic, climate, and anthropogenic variables as well as an interaction of sub-basin with human population density. As shown in Fig. 6A, this interaction produced a strong correspondence of model predictions with actual observations of a distinct relationship between forage fish CPUE and human population density in Central Basin compared to the other 3 sub-basins.

In contrast, above-threshold jellyfish CPUE exhibited no strong geographic or climate effects, and was positively related to human population density (Table 6, Fig. 6). The best model (Model 7, model probability $>0.98$ ) was the same as for forage fish, although significance tests indicated strong effects of only basin, commercial harvest, and human population density, and the basin $\times$ population density interaction were strong predictors $(p<0.05)$. Intriguingly, jellyfish CPUE was negatively associated with forage fish harvest. The positive relationship of human population density and jellyfish (Fig. 6C) exhibits an apparent decline at the highest levels of human population density, and the pattern of CPUE with NPGO (Fig. 6D) was highest during average NPGO years, suggesting possible unimodal effects of both predictors upon jellyfish CPUE.

\section{DISCUSSION}

Our analysis provides evidence for substantial changes in abundance and composition of Puget Sound forage fish populations during the last $40 \mathrm{yr}$, and suggests concurrent increases in the occurrence of large jellyfish aggregations in some sub-basins. Some species like Pacific herring and surf smelt exhibited declines within basins, while other species such as Pacific sand lance, three-spine stickleback, 
Table 6. Results of mixed-effects models of combinations of predictors listed as columns. Signs indicate direction of effects of predictors on total forage fish catch per unit effort $\left(\mathrm{CPUE}_{;} \mathrm{n} \mathrm{min}^{-1}\right)$ or above-threshold jellyfish CPUE (kg min $\left.{ }^{-1}\right)$. Unless otherwise noted, all parameter values strongly differed from $0(\mathrm{p}<0.05)$. Predictors that included Basin had 3 parameter estimates and so could have both positive and negative effects (+/-). Models are compared using the difference in Akaike's information criterion ( $\triangle \mathrm{AIC}$ ) and the probability of the model based on the $\triangle \mathrm{AIC}$ (best model shown in bold). Values listed as 'NA' for Model 8 indicate that the model did not converge on a solution. NPGO: North Pacific Gyre Oscillation

\begin{tabular}{|c|c|c|c|c|c|c|c|c|c|c|}
\hline Model & $\begin{array}{c}\text { Inter- } \\
\text { cept }\end{array}$ & Basin & Depth & NPGO & $\begin{array}{l}\text { Commer- } \\
\text { cial } \\
\text { landings }\end{array}$ & $\begin{array}{c}\text { Human } \\
\text { population } \\
\text { density }\end{array}$ & $\begin{array}{c}\text { Basin } \\
\times \\
\text { landings }\end{array}$ & $\begin{array}{c}\text { Basin } \\
\times \\
\text { density }\end{array}$ & $\Delta \mathrm{AIC}$ & $\begin{array}{c}\text { Probability } \\
\text { of } \\
\text { model }\end{array}$ \\
\hline \multicolumn{11}{|c|}{ Forage fish } \\
\hline 1 & + & $+/-$ & + & & & & & & 233.31 & $<0.0001$ \\
\hline 2 & + & $+/-$ & + & - & & & & & 126.93 & $<0.0001$ \\
\hline 3 & + & $+/-$ & + & - & - & & & & 118.78 & $<0.0001$ \\
\hline 4 & + & - & + & - & & - & & & 21.07 & $<0.0001$ \\
\hline 5 & + & $+/-$ & + & - & - & - & & & 15.59 & 0.0004 \\
\hline 6 & + & - & + & - & - & + & + & & 72.22 & $<0.0001$ \\
\hline 7 & + & - & + & - & - & - & & $+/-$ & 0.00 & 0.9954 \\
\hline 8 & + & - & + & - & - & - & $+/-$ & $+/-$ & 10.74 & 0.0046 \\
\hline \multicolumn{11}{|c|}{ Jellyfish } \\
\hline 1 & + & $+/-$ & $t^{\mathrm{a}}$ & & & & & & 8.69 & 0.0127 \\
\hline 2 & + & $+/-$ & $t^{\mathrm{a}}$ & $t^{\mathrm{a}}$ & & & & & 13.39 & 0.0012 \\
\hline 3 & + & $+/-$ & $t^{\mathrm{a}}$ & $+^{\mathrm{a}}$ & - & & & & 16.81 & 0.0002 \\
\hline 4 & + & $+/-$ & $t^{\mathrm{a}}$ & $t^{\mathrm{a}}$ & & $--^{a}$ & & & 14.17 & 0.0008 \\
\hline 5 & + & $+/-$ & $t^{\mathrm{a}}$ & $t^{a}$ & - & $-^{\mathrm{a}}$ & & & 16.93 & 0.0002 \\
\hline 6 & + & $+1-$ & $t^{\mathrm{a}}$ & $+^{\mathrm{a}}$ & - & - & $+/-$ & & 12.01 & 0.0024 \\
\hline 7 & - & $+/-$ & $-^{a}$ & $-{ }^{a}$ & - & + & & $+/-$ & 0.00 & 0.9824 \\
\hline 8 & NA & NA & NA & NA & NA & NA & NA & NA & - & - \\
\hline${ }^{\mathrm{a}} \mathrm{p}>0.0$ & & & & & & & & & & \\
\hline
\end{tabular}

and species of jellyfish exhibited increases in catch. Two of the 4 sub-basins we examined, viz. South Puget Sound and the Central Basin, showed greater divergence from historical conditions than the others, but all sub-basins appear to have undergone some change in composition, and these changes were correlated with human population density. Consequently, species composition in surface pelagic waters has apparently shifted from a state of relative similarity to one of high divergence among the sub-basins of Puget Sound (Fig. 4).

\section{Potential causes of change in abundance and composition}

Our results suggest that some sub-basins have reduced capacity to support forage fish that were highly abundant historically, and these patterns are consistent with additional studies documenting declines at adult life stages (Penttila 2007). Intriguingly, the magnitude of decline reported here is greater compared with the pattern in adult herring estimates, which suggests that compensatory processes after early stages mute overall population impacts on co- horts. Our findings agree with observations of largescale spatial and temporal covariation in forage fish (Hare et al. 1999, Reum et al. 2011, Gröger et al. 2014) or jellyfish (Condon et al. 2013) communities. We found a strong negative relationship between forage fish CPUE and NPGO, and climate-driven patterns have been substantiated for other forage fish populations in the northeastern Pacific Ocean (Reum et al. 2011, Liztow et al. 2014). However, large-scale climate indices like NPGO were insufficient to explain the substantial variation in forage fish CPUE across Puget Sound's sub-basins, which was better predicted by accounting for anthropogenic influences.

One explanation for compositional shifts is an increase in mortality of younger forage fish life stages (eggs, larvae, and other juvenile stages) resulting from anthropogenic impacts to shoreline areas, either through loss of critical spawning habitat or prevalence of pollutants that are particularly detrimental to early life-history stages (Rice 2006, West et al. 2008, Landis \& Bryant 2010, Shelton et al. 2014). Other explanations for anthropogenic causes of higher mortality are losses of preferred zooplankton prey due to nutrient inputs, eutrophic state, and hypoxia (Parsons \& Lalli 2002). 
These very conditions are also hypothesized to benefit jellyfish because they are more tolerant than forage fish to these states (Parsons \& Lalli 2002, Purcell et al. 2007, Richardson et al. 2009). In turn, jellyfish may impact forage fish by competing with them for zooplankton prey (Brodeur et al. 2008, 2014) or even consuming early life stages (Purcell \& Arai 2001). We did detect positive effects of human population density on jellyfish CPUE, and increases in the prevalence of large catches over time. However, we also observed reduced jellyfish CPUE in the most urbanized basin, suggesting that the highest levels of human population density may impact jellyfish as well as forage fish. It should be noted that the historical data did not discriminate among jellyfish species, leaving no opportunity to investigate potential compositional changes. Although not impacting the general conclusions of our study, the implications should be considered within a range of potential compositional shifts (e.g. increases in a single large-bodied species such as Cynea) corresponding with the patterns we observed.

We also detected some influence of commercial harvest on forage fish and jellyfish CPUE. Extensive commercial harvest of forage fish has been implicated as a cause of declines in forage fish abundance across the world (Pikitch et al. 2012) and in the North Pacific in particular (Litzow et al. 2014), as well as increases in jellyfish biomass resulting from release from predation (Purcell \& Arai 2001) or competition (Daskalov 2002). Mixed effects models suggested that commercial landings were less consequential than human population density, although both were important predictors of forage fish and jellyfish CPUE.

Commercial landings do not account for recreational harvest, which is more related to human population density than commercial fishing. Recreational harvest of forage fish is not rigorously controlled in the state of Washington (e.g. $10 \mathrm{lbs}$ [ 4.5 kg] of forage fish $d^{-1}$ person $^{-1}$ [all species combined], no fishing license required for smelts), and landings are not well-quantified for surf smelt, herring, sand lance, or anchovy. Data collected from 1980 to 2003 as part of a national recreational fisheries survey (Ihde et al. 2011) suggest that annual recreational harvest of forage fish in the region was $0.2-36 \%$ of commercial harvest across this time period and increased over time. Although recreational harvest is considered low for most species (Bargmann 1998), its impact on populations remains unclear.

Examining species-specific increases and declines over time offers additional insight into the potential drivers of change in composition and overall abundance of forage fish. We found evidence for declines in both surf smelt and Pacific herring, and increases in sand lance and stickleback. Surf smelt and herring share at least 3 characteristics: both are common in the pelagic water column, both are large enough to be sought by large predators including people, and both spawn exclusively in nearshore and intertidal zones. Following from these traits, these 2 species may be particularly sensitive to pelagic water quality problems, seabird and marine mammal predators, commercial and recreational fisheries, and shoreline buildout and hardening. In contrast, while sand lance are beach spawners, neither sand lance nor stickleback are targets for recreational or commercial harvest (development of a sand lance fishery is in fact disallowed by Washington Department of Fish and Wildlife policy), and stickleback in particular are relatively tolerant to environmental stress and pollutants (Deegan et al. 1997).

An alternate but non-exclusive hypothesis explaining spatial changes in CPUE over time is a change in cross-basin movement rates by forage fish and jellyfish (Bilkovic \& Roggero 2008). For example, forage fish may inhabit turbid areas to reduce risk of predation without greatly reducing prey consumption (DeRobertis et al. 2003), or prefer areas with higher arthropod zooplankton abundance, better temperature patterns, and higher dissolved oxygen to improve growth conditions. If such variables exhibited directional change over the time period of this study, changes in composition among sub-basins may reflect changes in movement (see Reum et al. 2013) into other sub-basins. Behavioral shifts may not be as severe an ecological impact as hypothesized changes in mortality or recruitment of forage fish, but they would nevertheless point to a reduction in the capacity of some sub-basins within Puget Sound to support forage fish, and consequently would still be of high concern to fisheries management entities.

\section{Potential methodological differences over time}

Our findings should be considered in light of methodological differences between recent and historical datasets. We examined 3 such differences that could influence results: day versus night sampling, spatial variation in sampling locations, and vessel/ gear deployment effects. When corrected for daynight differences, we found that our metrics were insensitive to different assumptions about activity patterns of individual species. Hence, while differing 
sampling times might influence the absolute level of abundance for some species, the overall conclusions of our study remain - i.e. that the abundance of certain species has changed over time in particular basins, and that species composition has diverged spatially over time.

Our findings were also robust to site-level variation. Despite variation in sampling sites in different datasets, explicitly including site variation in the analysis did not strongly influence interpretation of changes in composition over time. We did find a strong positive relationship between total forage fish CPUE and depth, but depths sampled did not differ strongly over time, and inclusion of the parameter improved model fit.

The third potential methodological challenge, viz. that gear was deployed or trawled in different ways, is the most difficult to test directly because cruise methodologies are confounded with time (historical versus recent). However, several observations suggest that methodological differences are likely not strong factors. First, consistent geographic variation has been observed in forage fish abundance and composition within sets of cruises where methodology has been constant. Cruises in 2003 and 2011 used similar methodology, yet in both years we observed high jellyfish abundance in the Central Basin and South Sound and low abundance of forage fish, and the reverse in Whidbey and Rosario Basins (Rice et al. 2012). Our findings are also consistent with observed declines in spawning adult herring within Puget Sound (Penttila 2007, Stick \& Lindquist 2009), which have been measured consistently over longer time periods. Finally, we tested for differences in capture efficiency by examining size distributions in historical compared to recent surveys; recent protocols were more efficient in capturing fish, a pattern opposite what we would expect if gear efficiency changes accounted for differences in recent and historical fish abundance. While we cannot rule out the influence of methodological biases, the evidence suggests that these biases are small, especially in light of the very large observed differences in fish abundance and species composition.

\section{IMPLICATIONS}

Our finding of strong divergence from a similar historical species composition across sub-basins has several important implications. These patterns are consistent with other research suggesting that anthropogenic influences can simplify community structure (Tewfik et al. 2005, Lotze et al. 2006), reducing resilience of particular areas (Thrush et al. 2008) to support forage fish populations. Scientists and managers working to understand and remediate impacts on forage fish populations in coastal and estuarine areas may benefit by incorporating anthropogenic factors and spatial scale into their analysis. This information can also help inform and prioritize protection and restoration actions. For example, our study suggests that Rosario and Whidbey Basins are relative hotspots for forage fish production, so habitat protection measures of nearshore habitats within these basins might improve resilience of the larger Puget Sound forage fish complex. Likewise, areas with relatively low urbanization within South and Central Basin might be better targeted for largescale restoration efforts (Simenstad et al. 2011).

In addition, our study suggests that discontinuous data sets can be valuable for determining ecosystem change. Long-term ( $>50 \mathrm{yr}$ ), continuous datasets relating to status of forage fish, jellyfish, and other aquatic systems are rare. Even fewer environments provide opportunities to establish paleorecords (e.g. Baumgartner et al. 1992, McKechnie et al. 2014) of population fluctuations over time scales surpassing a few human generations. Nevertheless, a wealth of data on aquatic systems was collected 40 to $60 \mathrm{yr}$ ago (e.g. Teal 1962, Sutcliffe 1972, Allen \& Horn 1975, Miller et al. 1977, Turner 1977), even though many such studies were short in duration. In the face of both local anthropogenic pressures and global climate change (Collie et al. 2008), examination of these datasets with newly collected information should shed further light on the breadth of ecological changes in our aquatic systems (Lotze et al. 2006).

Our analysis also suggests areas for important future research in other anthropogenically influenced estuary and coastal environments. Further study is needed on interactions between forage fish and jellyfish and how they may be exacerbated by anthropogenic changes to marine habitats. Likewise, inverse trends in abundance of forage fish and salmon (Fig. 2) beg the question of whether large pulses from hatcheries influence forage fish populations through competition or predation at sensitive life stages (Stewart et al. 1981). Additionally, the relative impacts of recreational versus commercial harvest on forage fish populations need better quantification (Ihde et al. 2011). Ecosystem models with scenarios that test for multiple anthropogenic impacts (Fulton et al. 2011, Kaplan et al. 2012) may help resolve their relative and cumulative risk upon forage fish and their prey, competitors, and predators. 
Acknowledgements. Funding for sampling in 2011 was provided by US EPA's National Estuary Program, Washington Department of Ecology's Intensively Monitored Watersheds Program, and Washington Department of Natural Resources. Funding for previous efforts was provided by the Northwest Fisheries Science Center, Army Corps of Engineers, Port of Bellingham, NOAA Fisheries, and Washington Department of Fish and Wildlife (WDFW). Funding for analysis and writing was provided by NOAA Sustainable Fisheries. We thank the senior staff of the Watershed Program at the Northwest Fisheries Science Center (P. Roni, T. Beechie, and G. Pess) for support and encouragement. Numerous people assisted in data collection efforts over the years, but we specifically thank Q. Stober and E. Salo for their meticulous recording of their data in Skagit Bay during the early 1970s (and to B. Miller for saving the data from the recycle bin). We also thank S. Bold, D. Lomax, B. Mowitt, J. Hall, and J. Chamberlin for their assistance with sampling on the recent surveys. J. Hall also helped synthesize environmental data and produced Fig. 1, and D. Rudy assisted with data re-entry of the historical data sets. K. Stick (WDFW) provided data on commercial landings across Puget Sound. The comments of J. Reum, R. Brodeur, R. Zabel, K. Stick, D. Lowry, and 3 anonymous reviewers improved the logic, flow, and readability of the manuscript.

\section{LITERATURE CITED}

Allen LG, Horn MH (1975) Abundance, diversity and seasonality of fishes in Colorado Lagoon, Alamitos Bay, California. Estuar Coast Mar Sci 3:371-380

> Araujo HA, Holt C, Curtis JMR, Perry RI, Irvine JR, Michielsens CGJ (2013) Building an ecosystem model using mismatched and fragmented data: a probabilistic network of early marine survival for coho salmon Oncorhynchus kisutch in the Strait of Georgia. Prog Oceanogr 115:41-52

Bakun A (2006) Fronts and eddies as key structures in the habitat of marine fish larvae: opportunity, adaptive response and competitive advantage. Sci Mar 70:105-122

Bargmann G (1998) Forage fish management plan — a plan for managing the forage fish resources and fisheries of Washington. Washington Department of Fish and Wildlife, Olympia, WA

Baumgartner T, Soutar A, Ferreira-Bartrina V (1992) Reconstruction of the history of Pacific sardine and northern anchovy populations over the past two millennia from sediments of the Santa Barbara Basin, California. Calif Coop Ocean Fish Invest Rep 33:24-40

Beck MW, Heck KL Jr, Able KW, Childers DL and others (2003) The role of nearshore ecosystems as fish and shellfish nurseries. Issues Ecol 11:1-12

Bilkovic DM, Roggero MM (2008) Effects of coastal development on nearshore estuarine nekton communities. Mar Ecol Prog Ser 358:27-39

Brodeur RD, Suchman CL, Reese DC, Miller TW, Daly EA (2008) Spatial overlap and trophic interactions between pelagic fish and large jellyfish in the northern California Current. Mar Biol 154:649-659

> Brodeur RD, Barceló C, Robinson KL, Daly EA, Ruzicka JJ (2014) Spatial overlap between forage fishes and the large medusa Chrysaora fuscescens in the northern California Current region. Mar Ecol Prog Ser 510:167-181

Burnham KP, Anderson DR (2002) Model selection and mul- timodel inference: a practical information theoretic approach. Springer-Verlag, New York, NY

Burns R (1985) The shape and form of Puget Sound. University of Washington Press, Seattle, WA

Clarke KR (1993) Non-parametric multivariate analysis of changes in community structure. Aust J Ecol 18:117-143

Clarke KR, Gorley RN (2006) Primer v6: user manual/ tutorial. PRIMER-E, Plymouth

Clarke KR, Warwick RM (2001) Change in marine communities: an approach to statistical analysis and interpretation. Plymouth Marine Laboratory, Plymouth

> Collie JS, Wood AD, Jeffries HP (2008) Long-term shifts in the species composition of a coastal fish community. Can J Fish Aquat Sci 65:1352-1365

Condon RH, Duarte CM, Pitt KA, Robinson KL and others (2013) Recurrent jellyfish blooms are a consequence of global oscillations. Proc Natl Acad Sci USA 110:10001005

> Cury P, Bakun A, Crawford RJ, Jarre A, Quiñones RA, Shannon LJ, Verheye HM (2000) Small pelagics in upwelling systems: patterns of interaction and structural changes in 'wasp-waist' ecosystems. ICES J Mar Sci 57:603-618

> Cury PM, Boyd IL, Bonhommeau S, Anker-Nilssen T and others (2011) Global seabird response to forage fish depletion - one-third for the birds. Science 334:1703-1706

Dahlgren CP, Kellison GT, Adams AJ, Gillanders BM and others (2006) Marine nurseries and effective juvenile habitats: concepts and applications. Mar Ecol Prog Ser 312:291-295

> Daskalov GM (2002) Overfishing drives a trophic cascade in the Black Sea. Mar Ecol Prog Ser 225:53-63

> De Robertis A, Ryer CH, Veloza A, Brodeur RD (2003) Differential effects of turbidity on prey consumption of piscivorous and planktivorous fish. Can J Fish Aquat Sci 60: 1517-1526

Deegan LA, Finn JT, Ayvazian SG, Ryder-Kieffer CA, Buonaccorsi J (1997) Development and validation of an estuarine biotic integrity index. Estuaries 20:601-617

Di Lorenzo E, Schneider N, Cobb KM, Chhak K and others (2008) North Pacific Gyre Oscillation links ocean climate and ecosystem change. Geophys Res Lett 35:L08607, doi: 10.1029/2007GL032838

Ebbesmeyer CC, Word JQ, Barnes CA (1988) Puget Sound: a fjord system homogenized with water recycled over sills by tidal mixing. In: Kjerfve B (ed) Hydrodynamics of estuaries. II. Estuarine case studies. CRC Press, Boca Raton, FL, p 17-30

Finlayson DP, Haugerud RA, Greenberg H, Logsdon MG (2000) Puget Sound Digital Elevation Model. Available at www.ocean.washington.edu/data/pugetsound/

- Flynn BA, Richardson AJ, Brierley AS, Boyer DC and others (2012) Temporal and spatial patterns in the abundance of jellyfish in the northern Benguela upwelling ecosystem and their link to thwarted pelagic fishery recovery. Afr J Mar Sci 34:131-146

Fresh KL (1979) Distribution and abundance of fishes occurring in the nearshore surface waters of northern Puget Sound, Washington. MS thesis, University of Washington, Seattle, WA

> Fulton EA, Link JS, Kaplan IC, Savina-Rolland M and others (2011) Lessons in modelling and management of marine ecosystems: the Atlantis experience. Fish Fish 12:171188

Griffiths SP, Young JW, Lansdell MJ, Campbell RA and others (2010) Ecological effects of longline fishing and 
climate change on the pelagic ecosystem off eastern Australia. Rev Fish Biol Fish 20:239-272

- Gröger JP, Hinrichsen HH, Polte P (2014) Broad-scale climate influences on spring-spawning herring (Clupea harengus, L.) recruitment in the western Baltic Sea. PLoS ONE 9:e87525

> Hare SR, Mantua NJ, Francis RC (1999) Inverse production regimes: Alaska and West Coast Pacific salmon. Fisheries 24:6-14

> Ihde TF, Wilberg MJ, Loewensteiner DA, Secor DH, Miller TJ (2011) The increasing importance of marine recreational fishing in the US: challenges for management. Fish Res 108:268-276

Kaplan IC, Horne PJ, Levin PS (2012) Screening California Current fishery management scenarios using the Atlantis end-to-end ecosystem model. Prog Oceanogr 102: 5-18

- Krutzikowsky GK, Emmett RL (2005) Diel differences in surface trawl fish catches off Oregon and Washington. Fish Res 71:365-371

> Landis WG, Bryant PT (2010) Using weight of evidence characterization and modeling to investigate the cause of the changes in Pacific Herring (Clupea pallasi) population dynamics in Puget Sound and at Cherry Point, Washington. Risk Anal 30:183-202

> Lauria V, Attrill MJ, Pinnegar JK, Brown A, Edwards M, Votier SC (2012) Influence of climate change and trophic coupling across four trophic levels in the Celtic Sea. PLoS ONE 7:e47408

Litzow MA, Mueter FJ, Hobday AJ (2014) Reassessing regime shifts in the North Pacific: incremental climate change and commercial fishing are necessary for explaining decadal scale biological variability. Glob Change Biol 20:38-50

Lotze HK, Lenihan HS, Bourque BJ, Bradbury RH and others (2006) Depletion, degradation, and recovery potential of estuaries and coastal seas. Science 312:1806-1809

Lynam CP, Lilley MKS, Bastian T, Doyle TK, Beggs SE, Hays GC (2011) Have jellyfish in the Irish Sea benefited from climate change and overfishing? Glob Change Biol 17: 767-782

Mantua NJ, Hare SR, Zhang Y, Wallace JM, Francis RC (1997) A Pacific interdecadal climate oscillation with impacts on salmon production. Bull Am Meteor Soc 78: 1069-1079

McCune B, Grace JB, Urban DL (2002) Analysis of ecological communities, Vol 28. MgM Software Design, Gleneden Beach, OR

McKechnie I, Lepofsky D, Moss ML, Butler VL and others (2014) Archaeological data provide alternative hypotheses on Pacific herring (Clupea pallasii) distribution, abundance, and variability. Proc Natl Acad Sci USA 111: E807-E816

Miller BS, Simenstad CA, Moulton LL, Fresh KL, Funk FC, Karp WA, Borton SF (1977) Puget Sound Baseline Program Nearshore Fish Survey. Fisheries Research Institute publication FRI-UW-7710. University of Washington, School of Fisheries, Seattle, WA

Moore SK, Mantua NJ, Kellogg JP, Newton JA (2008) Local and large-scale climate forcing of Puget Sound oceanographic properties on seasonal to interdecadal timescales. Limnol Oceanogr 53:1746-1758

Parsons TR, Lalli CM (2002) Jellyfish population explosions: revisiting a hypothesis of possible causes. Mer (Paris) 40: $111-121$
Pauly D, Graham W, Libralato S, Morissette L, Palomares MD (2009) Jellyfish in ecosystems, online databases, and ecosystem models. Hydrobiologia 616:67-85

Penttila DE (2007) Marine forage fishes in Puget Sound. Puget Sound Nearshore Partnership Report No. 2007-03. Seattle District U.S. Army Corps of Engineers, Seattle, WA

Pikitch E, Boersma PD, Boyd IL, Conover DO and others (2012) Little fish, big impact: managing a crucial link in ocean food webs. Lenfest Ocean Program, Washington, DC

> Purcell JE (2012) Jellyfish and ctenophore blooms coincide with human proliferations and environmental perturbations. Annu Rev Mar Sci 4:209-235

- Purcell JE, Arai MN (2001) Interactions of pelagic cnidarians and ctenophores with fish: a review. Hydrobiologia 451: $27-44$

> Purcell JE, Uye SI, Lo WT (2007) Anthropogenic causes of jellyfish blooms and their direct consequences for humans: a review. Mar Ecol Prog Ser 350:153-174

Reum JCP, Essington TE, Greene CM, Rice CA, Fresh KL (2011) Multiscale influence of climate on estuarine populations of forage fish: the role of coastal upwelling, freshwater flow and temperature. Mar Ecol Prog Ser 425: 203-215

Reum JCP, Essington TE, Greene CM, Rice CA, Fresh KL (2013) Biotic and abiotic controls on body size during a critical life history stage of a pelagic fish. Fish Oceanogr 22:324-336

Rice CA (2006) Effects of shoreline modification on a Northern Puget Sound beach: microclimate and embryo mortality in surf smelt (Hypomesus pretiosus). Estuar Coast 29:63-71

Rice CA, Duda JJ, Greene CM, Karr JR (2012) Geographic patterns of fishes and jellyfish in Puget Sound surface waters. Mar Coast Fish 4:117-128

> Richardson AJ, Bakun A, Hays GC, Gibbons MJ (2009) The jellyfish joyride: causes, consequences and management responses to a more gelatinous future. Trends Ecol Evol 24:312-322

> Schwing FB, Mendelssohn R (1997) Increased coastal upwelling in the California Current System. J Geophys Res 102:3421-3438

Shelton AO, Francis TB, Williams GD, Feist B, Stick K, Levin PS (2014) Habitat limitation and spatial variation in Pacific herring egg survival. Mar Ecol Prog Ser 514: 231-245

Simenstad CA, Ramirez M, Burke J, Logsdon M and others (2011) Historical change of Puget Sound shorelines: Puget Sound Nearshore Ecosystem Project Change Analysis. Puget Sound Nearshore Report No. 2011-01. Washington Department of Fish and Wildlife, Olympia, Washington, and U.S. Army Corps of Engineers, Seattle, WA

Stewart DJ, Kitchell JF, Crowder LB (1981) Forage fishes and their salmonid predators in Lake Michigan. Trans Am Fish Soc 110:751-763

Stick KC, Lindquist A (2009) 2008 Washington State herring stock status report. Stock Status Report FPA 09-05, Washington Department of Fish and Wildlife, Olympia, WA

Stober QJ, Salo EO (1973) Ecological studies of the proposed Kiket Island nuclear power site. Fisheries Research Institute FRI-UW-7304. University of Washington, Seattle, WA 
Strickland RM (1983) The fertile fjord. University of Washington Press, Seattle, WA

Sutcliffe W Jr (1972) Some relations of land drainage, nutrients, particulate material, and fish catch in two eastern Canadian bays. J Fish Res Board Can 29:357-362

Teal JM (1962) Energy flow in the salt marsh ecosystem of Georgia. Ecology 43:614-624

Tewfik A, Rasmussen JB, McCann KS (2005) Anthropogenic enrichment alters a marine benthic food web. Ecology 86:2726-2736

Thrush SF, Halliday J, Hewitt JE, Lohrer AM (2008) The effects of habitat loss, fragmentation, and community homogenization on resilience in estuaries. Ecol Appl 18: $12-21$

Editorial responsibility: Jana Davis, Annapolis, Maryland, USA
Trenberth KE, Caron JM (2000) The Southern Oscillation revisited: sea level pressures, surface temperatures and precipitation. J Clim 13:4358-4365

Turner RE (1977) Intertidal vegetation and commercial yields of penaeid shrimps. Trans Am Fish Soc 106: 411-416

> West JE, O'Neill SM, Ylitalo GM (2008) Spatial extent, magnitude, and patterns of persistent organochlorine pollutants in Pacific Herring (Clupea pallasi) populations in the Puget Sound (USA) and Strait of Georgia (Canada). Sci Total Environ 394:369-378

Zuur A, Ieno EN, Walker N, Saveliev AA, Smith GM (2009) Mixed effects models and extensions in ecology with R. Springer, New York, NY

Submitted: May 8, 2014; Accepted: February 20, 2015

Proofs received from author(s): March 25, 2015 